\title{
THERMAL REQUIREMENTS OF Ceraeochrysa cubana (Neuroptera: Chrysopidae) EMBRYONIC PERIOD SUBMITTED TO ARTIFICIAL DIETS AT ADULT STAGE
}

\author{
EXIGÊNCIAS TÉRMICAS DO PERÍODO EMBRIONÁRIO DE Ceraeochrysa cubana \\ (Neuroptera: Chrysopidae) SUBMETIDA A DIETAS ARTIFICIAIS NA FASE ADULTA
}

Gilmar da Silva NUNES ${ }^{1}$; Mileny dos Santos de SOUZA ${ }^{2}$; Thais Aparecida Vitoriano DANTAS ${ }^{3}$; Izabela Nunes do NASCIMENTO ${ }^{2}$; Gemerson Machado de OLIVEIRA ${ }^{4}$; Robério de OLIVEIRA $^{2}$; Jacinto de Luna BATISTA ${ }^{5}$

1. Doctoral Student of the Graduate Program in Agronomy - Agricultural Entomology, São Paulo State University (UNESP), Brazil. gilmarsilvanunes@gmail.com; 2. Doctoral Student of the Graduate Program in Agronomy, Federal University of Paraíba, Center for Agrarian Sciences (UFPB), Brazil. 3. Master Student of the Graduate Program in Biodiversity, Federal University of Paraíba (CCA-

UFPB), Brazil. 4. Master Student of the Graduate Program in Agronomy, Federal University of Paraíba (CCA-UFPB), Brazil. 5. Professor at the Federal University of Paraíba (CCA-UFPB), Brazil.

\begin{abstract}
Green lacewings can be mass reared to market their eggs. The ideal temperature is a main factor for egg storage or scheduling of insect production. This study aimed to evaluate the influence of Ceraeochrysa cubana adult feeding on incubation period and feasibility off eggs storage under different temperatures. Adults were submitted to four artificial diets: honey + brewer's yeast (standard diet), molasses + brewer's yeast, honey + bee pollen and molasses + bee pollen. Incubation period was recorded keeping eggs at six different temperatures: $21,23,25,27,29$ and $31{ }^{\circ} \mathrm{C}$. requirements. We determined the duration of the incubation period and egg feasibility of $C$. cubana. In addition, we estimated the base temperature $(T b)$ and thermal threshold $(K)$ for the green lacewing incubation. Regardless of diet, incubation period decreases according to increased temperature, which is indicated between 21 and $29{ }^{\circ} \mathrm{C}$ for better development and egg feasibility. Adult feeding influences thermal constant, however, does not influence base temperature of the eggs, which varies from 15 to $18{ }^{\circ} \mathrm{C}$. Our results can serve as a basis for the choice of adults' diet and temperature for the storage of eggs during the mass rearing of C. cubana.
\end{abstract}

KEYWORDS: Egg storage. Green lacewings. Mass rearing. Temperature.

\section{INTRODUCTION}

The high infestation intensities of arthropod-pests that affect crops of economic importance generate considerable damage to agricultural production. Biological control is one of the activity reduction tactics of these individuals, a basic pillar for the implementation of integrated pest management (IPM) (NARANJO et al., 2015).

Among the natural control agents of insectpests, predator insects known as green lacewings (Neuroptera: Chrysopidae) are studied (LIRA; BATISTA, 2006; BEZERRA et al., 2009; PAPPAS et al., 2011; TAVARES et al., 2011; OLIVEIRA et al., 2016). In Brazil, Chrysoperla and Ceraeochrysa genus stands out. Ceraeochrysa cubana species (Hagen, 1861) (Neuroptera: Chrysopidae), known commonly as trash-carrying chrysopids, is found in different crops, as maize and tomato (RESENDE et al., 2014; MOURA et al 2015), and is an important predator of many pests in its larval stage (ALCANTRA et al., 2008; OLIVEIRA et al., 2014; NUNES et al., 2017). In addition, its ease rearing outside natural environment is a factor considered as essential. In adult stage lacewings feed on nectar, pollen and honeydew (PARRA et al., 2002; MORGADO et al., 2014). These foods can be replaced by artificial diets consisted of energy and protein sources in its formulation.

Less expensive diets optimize mass rearing of insect predators, which aim at producing on a scale that allows its release for pest control in field (VAN LENTEREN, 2012). In large-scale rearing, lacewing feeding can influence longevity of adults and egg production, as well in period and feasibility of incubation period (VENZON et al., 2006; OLIVEIRA et al., 2009). The temperature is another importance factor for development stage of lacewings (CANARD; PRINCIPI, 1984), mainly aiming at egg storage for marketing or scheduling for the management of insect production (LÓPEZARROYO et al., 2000; AMARAL et al., 2013; MORGADO et al., 2014). Thus, this study aimed to evaluate the influence of $C$. cubana adult feeding on incubation period and feasibility off eggs storage under different temperature, characterizing base temperature and thermal constant in order to determine a temperature range in which eggs can be submitted. 


\section{MATERIAL AND METHODS}

This study was conducted in the Laboratory of Entomology of the Federal University of Paraíba. C. cubana adults kept under rearing in laboratory were used, with an average temperature of $25 \pm 2$ ${ }^{\circ} \mathrm{C}$, relative humidity of $75 \pm 10 \%$ and photoperiod of 12 hours. Adults were reared in PVC cylindrical cages, locked at the bottom with zinc lid and on top with white voile fabric, and white paper internally adhered to cages. One artificial diet consisted of honey and brewer's yeast was provided for lacewings in equal proportions (1:1) arranged in a rectangular plastic material $(2.5 \times 0.5 \mathrm{~cm})$, and distilled water provided on hydrophilic cotton stored in polyethylene lids.

Green lacewing eggs were collected and placed for hatching in plastic plates $\left(\right.$ ELISA $\left.^{\circledR}\right)$. After hatching, larvae were fed with Anagasta kuehniella (Zeller, 1879) (Lepidoptera: Pyralidae) eggs for obtaining adults. A total of 10 couples of $C$. cubana were stored in small transparent plastic cages (one couple per cage). Four different diets were used: Honey + brewer's yeast; Molasses + brewer's yeast; Honey + bee pollen; Molasses + bee pollen. We used honey associated with brewer's yeast as standard diet. The bee pollen in the artificial diets was based on Loru et al. (2014), and molasses in due to the fact that this component has facility of acquisition and possibility of utilization as food attractants for lacewings adults under field conditions (KUNKEL; COTTRELL, 2014).

Sugar cane molasses was purchased at supermarket. Honey was derived from the production of Beekeeping sector, Campus II of UFPB; brewer's yeast and bee pollen from herbal medicines store. Diets were provided in adapted transparent plastic material (polyethylene), with 0.5 $\mathrm{x} 1.5 \mathrm{~cm}$ dimensions. Water was placed in hydrophilic cotton stored in lids for plastic pots (1.0 $\mathrm{cm}$ height $\mathrm{x} 1.5 \mathrm{~cm}$ diameter) with the aid of spray bottle. The different diets provided for the $C$. cubana couples in each temperature were replaced every two days.

During feeding of adults with diets cited above, eggs produced were collected and separated into ELISA plates and subjected to different temperatures: $21,23,25,27,29$ and $31{ }^{\circ} \mathrm{C}$, in airconditioned chambers of Biological Oxigen Demand (B.O.D.) type, with relative humidity of 70 $\pm 10 \%$ and of $12 \mathrm{~L}: 12 \mathrm{D}$ photoperiod. So, the following parameters were evaluated: duration of incubation period (days) and egg feasibility (hatchability) (\%). These parameters were used to determine the duration of the incubation period of C. cubana and ratio between hatching number of larvae without apparent defects. Days of development, development speed, base temperature $(T b)$ and thermal threshold $(K)$ were also estimated for incubation period. We used four replications for each diet with 10 samples/replication, totaling 40 plots/temperature.

The statistical design adopted for data analysis related to the effect of each separate temperature on incubation period in each treatment was completely randomized. Data were submitted to analysis of variance (ANOVA) and treatment means were compared by Tukey test at $5 \%$ probability. To evaluate the feasibility of incubation period, a $4 \times 6$ factorial scheme was adopted (diets $\mathrm{x}$ temperatures). Interaction data between different diets with temperatures and duration of embryonic period were submitted to polynomial regression testing, and $T b$ and $K$ were estimated from the hyperbola equation (HADDAD et al., 1999). The statistical software used for research was Sisvar ${ }^{\circledR} 5.3$ Build 77 (FERREIRA, 2011).

\section{RESULTS}

At $21{ }^{\circ} \mathrm{C}$ temperature was observed that the shorter duration of $C$. cubana incubation period occurred when the green lacewing was fed with honey + bee pollen. There was no statistical difference in duration of $C$. cubana incubation period between diets, when eggs were submitted to 23, 25, 27 and $29{ }^{\circ} \mathrm{C}$ temperatures. By rising temperature to $31{ }^{\circ} \mathrm{C}$, hatching was faster when adults were mainly fed with standard diet and honey + bee pollen, approximately for three days (Table $1)$.

We observed $T b$ values for $C$. cubana incubation period ranging from 14.4 to $15.7^{\circ} \mathrm{C}$, and thermal constant, calculated according to speed of development curve, between 48.3 and 54.9 degreesday. According to confidence intervals, diets provide no effect on base temperature, but influence thermal constant. The honey + brewer's yeast and molasses + brewer's yeast diets are approaching the interval found in molasses + bee pollen diet and are far from the obtained interval for honey + bee pollen diet (Table 2).

From variance analyses, significant interaction was observed between treatments and temperature under days of development $(\mathrm{p}>0.01)$ and development speed $(\mathrm{p}<0.01)$ of $C$. cubana incubation period, where all treatments were significantly linearly at all temperatures (Figure 1). 
Table 1. Duration of $C$. cubana incubation period submitted to different diets at adult stage and with eggs kept under different temperature in B.O.D air-conditioned chambers, $\mathrm{RH}$ of $70 \pm 10 \%$ and 12L:12D photoperiod

\begin{tabular}{llllll}
\hline \multirow{2}{*}{ Temperature } & Diets & \multicolumn{5}{l}{} & $\mathrm{CV}(\%)$ \\
\cline { 2 - 5 } & $\mathrm{H}+\mathrm{BY}$ & $\mathrm{M}+\mathrm{BY}$ & $\mathrm{H}+\mathrm{BP}$ & $\mathrm{M}+\mathrm{BP}$ & \\
\hline $21{ }^{\circ} \mathrm{C}$ & $8.1 \pm 0.07 \mathrm{a}$ & $7.7 \pm 0.42 \mathrm{ab}$ & $7.3 \pm 0.25 \mathrm{c}$ & $7.5 \pm 0.21 \mathrm{ab}$ & 6.29 \\
$23^{\circ} \mathrm{C}$ & $7.0 \pm 0.04 \mathrm{a}$ & $6.8 \pm 0.16 \mathrm{a}$ & $6.9 \pm 0.09 \mathrm{a}$ & $7.0 \pm 0.08 \mathrm{a}$ & 2.69 \\
$25^{\circ} \mathrm{C}$ & $6.7 \pm 0.23 \mathrm{a}$ & $6.5 \pm 0.05 \mathrm{a}$ & $7.1 \pm 0.20 \mathrm{a}$ & $6.9 \pm 0.11 \mathrm{a}$ & 4.31 \\
$27{ }^{\circ} \mathrm{C}$ & $4.1 \pm 0.05 \mathrm{a}$ & $4.3 \pm 0.17 \mathrm{a}$ & $3.7 \pm 0.32 \mathrm{a}$ & $4.2 \pm 0.17 \mathrm{a}$ & 8.65 \\
$29{ }^{\circ} \mathrm{C}$ & $3.3 \pm 0.18 \mathrm{a}$ & $3.0 \pm 0.00 \mathrm{a}$ & $3.4 \pm 0.00 \mathrm{a}$ & $3.3 \pm 0.07 \mathrm{a}$ & 3.95 \\
$31{ }^{\circ} \mathrm{C}$ & $2.6 \pm 0.23 \mathrm{~b}$ & $2.9 \pm 0.33 \mathrm{~b}$ & $3.7 \pm 0.21 \mathrm{ab}$ & $3.3 \pm 0.13 \mathrm{a}$ & 14.45 \\
\hline
\end{tabular}

Means \pm standard error followed by same lowercase letter in line do not statistically differ by Tukey test $(\mathrm{p}<0.05)$. $\mathrm{H}+\mathrm{BY}=$ honey + brewer's yeast; $\mathrm{M}+\mathrm{BY}=$ molasses + brewer's yeast; $\mathrm{H}+\mathrm{BP}=$ honey + bee pollen; $\mathrm{M}+\mathrm{BP}=$ molasses + bee pollen.

Table 2. Linear regression equations between temperatures $\left(21,23,25,27,29,31{ }^{\circ} \mathrm{C}\right)$ and speed of development (1/D) to determine base temperature $(T b)$ and thermal constant $(K)$ in development of $C$. cubana incubation period (adults submitted to different diets)

\begin{tabular}{lllllll}
\hline Diets & $a^{*}$ & $b^{* *}$ & $\mathrm{Pr}>\mathrm{F}$ & $\mathrm{R}^{2}$ & $T b\left({ }^{\circ} \mathrm{C}\right)\left(\mathrm{CI}^{1}\right)$ & $K$ (Degree-days) $(\mathrm{CI})$ \\
\hline $\mathrm{H}+\mathrm{BY}$ & -0.4978 & 0.0279 & $<0.0001$ & 0.9245 & $17.8(13.2-23.7)$ & $35.8(32.4-41.0)$ \\
$\mathrm{M}+\mathrm{BY}$ & -0.4339 & 0.0254 & $<0.0001$ & 0.9116 & $17.1(12.3-23.5)$ & $39.3(34.8-45.0)$ \\
$\mathrm{H}+\mathrm{BP}$ & -0.2622 & 0.0182 & $<0.0001$ & 0.7731 & $14.4(7.9-23.2)$ & $54.9(47.5-68.8)$ \\
$\mathrm{M}+\mathrm{BP}$ & -0.3253 & 0.0207 & $<0.0001$ & 0.8873 & $15.7(9.9-23.6)$ & $48.3(42.2-58.1)$ \\
\hline
\end{tabular}

${ }^{\mathrm{I}}$ Confidence intervals (95\%); Coefficient *linear and **angular from line obtained by regression equation for $1 / \mathrm{D} ; T b=-a / b ; K=$ $1 / b . \mathrm{H}+\mathrm{BY}=$ honey + brewer's yeast; $\mathrm{M}+\mathrm{BY}=$ molasses + brewer's yeast; $\mathrm{H}+\mathrm{BP}=$ honey + bee pollen; $\mathrm{M}+\mathrm{BP}=$ molasses + bee pollen
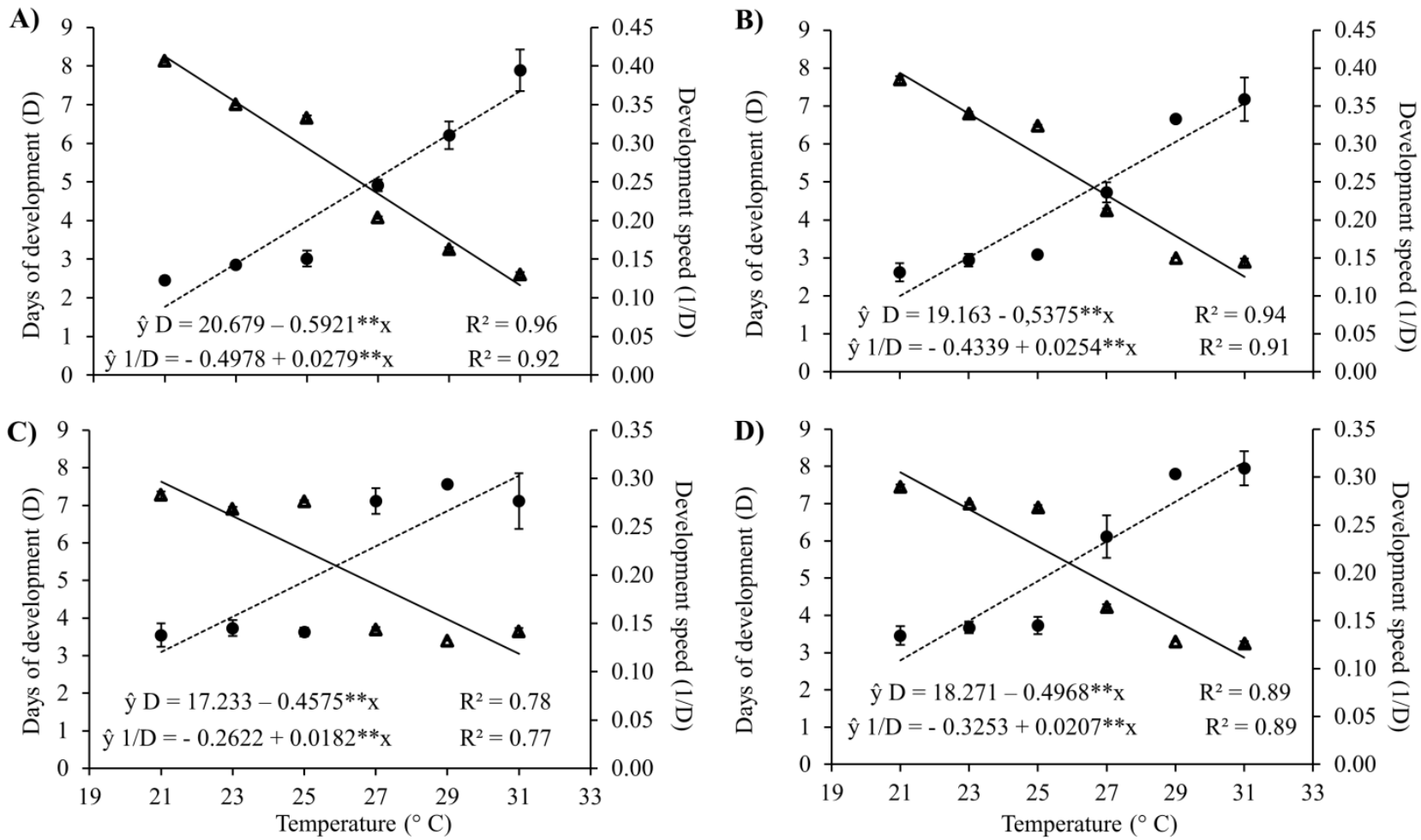

Figure 1. Regression curves adjusted for influence of different diets for C. cubana on days of development $(-)$ and development speed (----) of its incubation period (eggs subjected to different temperatures). A) $\mathrm{H}+\mathrm{BY}=$ honey + brewer's yeast; $\mathrm{B}) \mathrm{M}+\mathrm{BY}=$ molasses + brewer's yeast; $\mathrm{C}) \mathrm{H}+\mathrm{BP}$ $=$ honey + bee pollen; $\mathrm{D}) \mathrm{M}+\mathrm{BP}=$ molasses + bee pollen . 
The feasibility of C. cubana incubation period fed with different diets statistically differ in relation to $27{ }^{\circ} \mathrm{C}$ temperature, by having $100 \%$ of viable eggs in molasses + brewer's yeast diet and $75 \%$ in molasses + bee pollen diet. By comparing the feasibility of the eggs within each temperature according to food provided for the adults of lacewing, it was found that only in diets containing bee pollen has temperature influence on incubation period (Table 3). When diet with molasses + bee pollen diet was provided to $C$. cubana adults we observed lower value of egg feasibility at $27{ }^{\circ} \mathrm{C}$ temperature (Table 3).

Table 3. Feasibility (\%) of C. cubana incubation period submitted to different diets with eggs kept under different temperatures in B.O.D. chambers, RH of $70 \pm 10 \%$ and $12 \mathrm{~L}: 12 \mathrm{D}$ photoperiod

\begin{tabular}{|c|c|c|c|c|}
\hline \multirow{2}{*}{ Temperature } & \multicolumn{4}{|l|}{ Diets } \\
\hline & $\mathrm{H}+\mathrm{BY}$ & $\mathrm{M}+\mathrm{BY}$ & $\mathrm{H}+\mathrm{BP}$ & $\mathrm{M}+\mathrm{BP}$ \\
\hline $21^{\circ} \mathrm{C}$ & $92.5 \pm 2.5 \mathrm{Aa}$ & $87.5 \pm 2.5 \mathrm{Aa}$ & $90.0 \pm 5.8 \mathrm{Aa}$ & $90.0 \pm 4.1 \mathrm{ABa}$ \\
\hline $23^{\circ} \mathrm{C}$ & $95.0 \pm 2.9 \mathrm{Aa}$ & $95.0 \pm 2.9 \mathrm{Aa}$ & $85.0 \pm 5.0 \mathrm{Aa}$ & $87.5 \pm 6.3 \mathrm{ABa}$ \\
\hline $25^{\circ} \mathrm{C}$ & $92.5 \pm 4.8 \mathrm{Aa}$ & $97.5 \pm 2.5 \mathrm{Aa}$ & $97.5 \pm 2.5 \mathrm{Aa}$ & $97.5 \pm 2.5 \mathrm{Aa}$ \\
\hline $27^{\circ} \mathrm{C}$ & $92.5 \pm 4.8 \mathrm{Aab}$ & $100.0 \pm 0.0 \mathrm{Aa}$ & $82.5 \pm 6.3 \mathrm{Abc}$ & $75.0 \pm 2.9 \mathrm{Cc}$ \\
\hline $29^{\circ} \mathrm{C}$ & $100.0 \pm 0.0 \mathrm{Aa}$ & $100.0 \pm 0.0 \mathrm{Aa}$ & $95.0 \pm 5.0 \mathrm{Aa}$ & $90.0 \pm 4.1 \mathrm{ABa}$ \\
\hline $31^{\circ} \mathrm{C}$ & $92.5 \pm 4.8 \mathrm{Aa}$ & $100.0 \pm 0.0 \mathrm{Aa}$ & $97.5 \pm 2.5 \mathrm{Aa}$ & $90.0 \pm 4.1 \mathrm{ABa}$ \\
\hline
\end{tabular}

Mean \pm standard errors followed by same capital letters in the column and lowercase in line are statistically differ by Tukey test ( $\mathrm{p}<$ $0.05) ; \mathrm{CV}(\%)=7.35$. H+BY = honey + brewer's yeast; $\mathrm{M}+\mathrm{BY}=$ molasses + brewer's yeast $\mathrm{H}+\mathrm{BP}=$ honey + bee pollen; $\mathrm{M}+\mathrm{BP}=$ molasses + bee pollen

\section{DISCUSSION}

As temperature was enhanced from $21^{\circ} \mathrm{C}$ to $31{ }^{\circ} \mathrm{C}$, duration and development speed of incubation period tended to be decreasing and increasing, respectively. The hatching time of larvae was higher in standard treatment at lower temperatures and decreased with raising temperature. The same occurred in molasses + brewer's yeast treatment; however, values of stage duration are lower at mild temperatures and increase compared to standard diet only when temperature exceeds $29{ }^{\circ} \mathrm{C}$. Rather than diets, differences between duration of incubation period can be different among chrysopid species. Decreased duration of incubation period due to increased temperature are common to lacewings, as observed for C. externa (ALBUQUERQUE et al., 1994; PESSOA et al., 2009), Chrysoperla raimundoi Freitas \& Penny, 2001 (FREITAS; PENNY, 2001), and Chrysoperla carnea (Stephens, 1836) (NADEEM et al., 2012) at temperatures ranging between 20 and $35^{\circ} \mathrm{C}$.

At assessment of $C$. externa embryonic period duration fed on Alabama argillacea (Hübner, 1818) (Lepidoptera: Noctuidae) at larval stage and on standard diet at adulthood, Silva et al. (2002) showed decrease as temperature enhanced from 15 ${ }^{\circ} \mathrm{C}$ to $30{ }^{\circ} \mathrm{C}$. Decrease of $32 \%$ in duration of $C$. raimundoi embryonic period was observed by feeding adults with standard diet and eggs subjected to a temperature of $31{ }^{\circ} \mathrm{C}$ (LAVAGNINI et al., 2009). The values observed by these authors are equal to those observed in this study, when $C$. cubana is fed on the same diet and diet based on molasses and brewer's yeast.

Our results indicated that there is relationship among diets for adults to thermal requirements of $C$. cubana incubation period, and some values are according to other studies with other chrysopid species. The thermal constant observed in honey + bee pollen diet is similar to that reported for $C$. raimundoi (LAVAGNINI et al., 2009). Bezerra et al. (2012) found values of $T b=$ 11.08 and $K=51.39$ for Chrysoperla genanigra Freitas, 2003 (Neuroptera: Chrysopidae) incubation period.

It is observed in literature recommendations and optimal temperature ranges for feasibility of lacewing eggs, between 20 and $25^{\circ} \mathrm{C}$ (PESSOA et al., 2009; BEZERRA et al., 2012). Diet based on molasses and brewer's yeast provided $100 \%$ of feasibility at temperatures between $27^{\circ} \mathrm{C}$ and $31^{\circ} \mathrm{C}$. This temperature range is according to that evidenced for the feasibility of Dichochrysa prasina (Burmeister, 1839) (Neuroptera: Chrysopidae) eggs (PAPPAS et al., 2008).

The relationship between temperature and embryonic stage of lacewings is important for its development and survival and is fundamental for storage of eggs and stock control in mass rearing (LÓPEZ-ARROYO et al., 2000). The results of 
Amaral et al. (2013) confirmed that the development of $C$. externa embryo is lower at temperatures of 12 ${ }^{\circ} \mathrm{C}$ and should be removed from the storage according to age at which egg was subjected to storage. Our results can be important to supervision of the $C$. cubana egg storage at mass rearing conditions.

\section{CONCLUSIONS}

Regardless of the diet used for C. cubana, the duration of embryonic period decreases with increased temperature at which eggs are subjected.

Temperatures between $21{ }^{\circ} \mathrm{C}$ and $29{ }^{\circ} \mathrm{C}$ are the most suitable for the storage of eggs, and the interaction between diets based on molasses + brewer's yeast with temperature of $27^{\circ} \mathrm{C}$ promotes lower $C$. cubana egg hatchability.

The thermal constant of incubation period is influenced by the food provided for adults, in contrast, base temperature is not influenced, ranging from 15 to $18{ }^{\circ} \mathrm{C}$.

\section{ACKNOWLEDGMENTS}

The authors thank to Conselho Nacional de Desenvolvimento Científico e Tecnológico (CNPq), Coordenação de Aperfeiçoamento de Pessoal de Nível Superior (CAPES) for granting scholarships, and José Bruno Malaquias for statistical analysis support.

RESUMO: Os crisopídeos podem ser criados em grande escala para comercialização dos ovos. A temperatura ideal é um fator decisivo para o armazenamento de ovos ou escalonamento da produção do inseto. Essa pesquisa objetivou avaliar a influência da alimentação dos adultos de Ceraeochrysa cubana no período de incubação e na viabilidade dos ovos armazenados em diferentes temperaturas. Os adultos foram submetidos a quatro dietas artificiais: mel + lêvedo de cerveja (padrão), melado + lêvedo de cerveja, mel + pólen apícola e melado + pólen apícola. O período de incubação foi registrado mantendo-se os ovos em seis temperaturas diferentes: $21,23,25,27,29$ e $31^{\circ} \mathrm{C}$. Determinou-se a duração do período de incubação e a viabilidade dos ovos de $C$. cubana. Além disso, estimaram-se a temperatura base (Tb) e a constante térmica $(K)$ para o período de incubação do crisopídeo. Independente da dieta, o período de incubação decresce de acordo com o aumento da temperatura, a qual tem faixa indicada para melhor desenvolvimento e viabilidade dos ovos entre 21 e $29^{\circ} \mathrm{C}$. A alimentação dos adultos influencia na constante térmica, mas não influencia na temperatura base dos ovos, que varia de 15 a $18{ }^{\circ} \mathrm{C}$. Nossos resultados podem servir de base para a escolha da dieta dos adultos e da temperatura para armazenamento dos ovos durante a criação massal de C. cubana.

PALAVRAS-CHAVE: Criação massal. Crisopídeos. Estocagem de ovos. Temperatura.

\section{REFERENCES}

ALBUQUERQUE, G. S.; TAUBER, C. A.; TAUBER, M. J. Chrysoperla externa (Neuroptera: Chrysopidae): life history and potential for biological control in Central and South America. Biological Control, Orlando, v. 4, p. 8-13. 1994. https://doi.org/10.1006/bcon.1994.1002

ALCANTRA, E.; CARVALHO, C. F.; SANTOS, T. M. D.; SOUZA, V.; SANTA-CECÍLIA, L. V. C. Aspectos biológicos e capacidade predatória de Ceraeochrysa cubana (Hagen, 1861) (Neuroptera: Chrysopidae) alimentada com Aphis gossypii Gl;over, 1877 (Hemiptera: Aphididae) em diferentes temperaturas. Ciência e Agrotecnologia, Lavras, v. 32, n. 4, p. 1047-1054, 2008. https://doi.org/10.1590/S1413-70542008000400003

AMARAL, B. B.; SOUZA, B.; BEZERRA, C. E. S.; LUIZA, A.; SOUZA, V.; CARVALHO, C. F. Storing eggs of Chrysoperla externa (Hagen, 1861) (Neuroptera: Chrysopidae) for management of large-scale rearing. Açoreana, Açores, v. 9, p. 103-109, 2013.

BEZERRA, C. E. S.; NOGUEIRA, C. H. F.; SOMBRA, K. D. S.; DEMARTELARE, A. C. F.; ARAUJO, E. L. Crisopídeos (Neuroptera: Chrysopidae): aspectos biológicos, potencial de uso e perspectivas futuras. Revista Caatinga, Mossoró, v. 22, p. 1-5, 2009. 
BEZERRA, C. E. S.; TAVARES, P. K. A.; NOGUEIRA, C. H. F.; MACEDO, L. P. M.; ARAUJO, E. L. Biology and thermal requirements of Chrysoperla genanigra (Neuroptera: Chrysopidae) reared on Sitotroga cerealella (Lepidoptera: Gelechidae.) eggs. Biological Control, Orlando, v. 60, p. 113-118, 2012. https://doi.org/10.1016/j.biocontrol.2011.11.010

CANARD, M.; PRINCIPI, M. M. Development of Chrysopidae. In: CANARD, M.; SÉMÉRIA, Y.; NEW, T. R. (eds): Biology of Chrysopidae, The Hague: W. Junk. 1984. 308 pp.

FERREIRA, D. F. Sisvar: a computer statistical analysis system. Ciência e Agrotecnologia, Lavras, v. 35, p. 1039-1042, 2011.

FREITAS, S.; PENNY, N. D. The green lacewings (Neuroptera: Chrysopidae) of Brazilian agro-ecosystems. Proceedings of the California Academy of Sciences, San Francisco, v. 52, p. 245-395, 2001.

HADDAD, L. L.; PARRA, J. R. P.; MORAES, R. C. B. Métodos para estimar os limites térmicos inferior e superior de desenvolvimento de insetos. FEALQ, Piracicaba. 1999. 29 pp.

KUNKEL, B. A.; COTTRELL, T. E. Oviposition response of green lacewings (Neuroptera: Chrysopidae) to aphids (Hemiptera: Aphididae) and potential attractants on pecan. Environmental Entomology, Lanham. 36, n. 3, p. 577-583, 2014. https://doi.org/10.1603/0046-225X(2007)36[577:OROGLN]2.0.CO;2

LAVAGNINI, T. C.; FREITAS, S.; BEZERRA, A. L. Aspectos biológicos de Chrysoperla raimundoi Freitas \& Penny (Neuroptera, Chrysopidae). Revista Brasileira de Entomologia, São Paulo, v. 53, p. 629-634, 2009. https://doi.org/10.1590/S0085-56262009000400013

LIRA, R. S.; BATISTA, J. L. Aspectos biológicos de Chrysoperla externa alimentada com o pulgão-da-ervadoce. Revista de Biologia e Ciências da Terra, Campina Grande, v. 26, p. 20-35. 2006.

LÓPEZ-ARROYO, J. I.; TAUBER, C. A.; TAUBER, M. J. Storage of lacewing eggs: post storage hatching and quality of subsequent larvae and adults. Biological Control, Orlando, v. 18, p. 165-171, 2000.

https://doi.org/10.1006/bcon.2000.0821

LORU, L.; FOIS, X.; RAMASANI, S. V.; FADDA, L. M.; PANTALEONI, R. A. An innovative, low-cost, small-scale rearing method for green lacewings (Neuroptera Chrysopidae). Biodiversity Journal, Palermo, v. 5, n. 2, p. 221-224, 2014.

MORGADO, L. N.; RESENDES, R.; MOURA, M.; VENTURA, M. A. M. Pollen resources used by Chrysoperla agilis (Neuroptera: Chrysopidae) in the Azores, Portugal. European Journal of Entomology, České Budějovice, v. 111, p. 143-146, 2014.

MOURA, A. P.; GUIMARÃES, J. A.; COSTA, R. I. F.; BRIOSO, P. T. Species of Chrysopidae (Neuroptera) associated to trellised tomato crops in two cities of Rio de Janeiro State, Brazil. Arquivos do Instituto Biológico, São Paulo, v. 52, p. 1-4, 2015. https://doi.org/10.1590/1808-1657000412013

NADEEM, S.; HAMED, M.; ISHFAQ, M.; NADEEM, M. K.; HASNAIN, M.; SAEED, N. A. Effect of storage duration and low temperatures on the developmental stages of Chrysoperla carnea (Stephens) (Neuroptera: Chrysopidae). Journal of Animal and Plant Sciences, Lahore, v. 24, p. 1569-1572, 2014.

NADEEM, S.; HAMED, M.; NADEEM, M. K.; HASNAIN, M.; ATTA, B. M.; SAEED, N. A.; ASHFAQ, M. Comparative study of developmental and reproductive characteristics of Chrysoperla carnea (Stephens) (Neuroptera: Chrysopidae) at different rearing temperatures. Journal of Animal and Plant Sciences, Lahore, v. 22, p. 399-402, 2012. 
NARANJO S. E.; ELLSWORTH P. C.; FRISVOLD G. B. Economic value of biological control in integrated pest management of managed plant systems. Annual Review of Entomology, Palo Alto, v. 60, p. 621-645, 2015. https://doi.org/10.1146/annurev-ento-010814-021005

NUNES, G. S.; NASCIMENTO, I. N.; SOUZA, G. M. M.; OLIVEIRA, R.; OLIVEIRA, F. Q.; BATISTA, J. L. Biological aspects and predation behavior of Ceraeochrysa cubana against Spodoptera frugiperda. Revista Brasileira de Ciências Agrárias, Recife, v. 12, n. 1, p. 20-25, 2017. https://doi.org/10.5039/agraria.v12i1a5411

OLIVEIRA, A. S.; AUAD, A. M.; SOUZA, B.; CARVALHO, C. A.; SOUZA, L. S.; AMARAL, R. L.; SILVA, D. M. Benefícios do mel e pólen de forrageiras nos parâmetros biológicos de Chrysoperla externa (Hagen, 1861) (Neuroptera: Chrysopidae). Arquivos do Instituto Biológico, São Paulo, v. 76, p. 583-588, 2009.

OLIVEIRA, R.; ALVES, P. R. R.; COSTA, W. J. D.; BATISTA, J. L.; BRITO, C. H. Capacidade predatória de Ceraeochrysa cubana sobre Aleurocanthus woglumi. Revista Caatinga, Mossoró, v. 27, p. 177-182, 2014.

OLIVEIRA, R.; BARBOSA, V. O.; LAVRA, D. V.; OLIVEIRA, F. Q.; BATISTA, J. L.; BRITO, C. H. Development and reproduction of Ceraeochrysa cubana (Neuroptera: Chrysopidae) fed with Aleurocanthus woglumi (Hemiptera: Aleyrodidae). Semina. Ciências Agrárias, Londrina, v. 37, p. 17-24, 2016. https://doi.org/10.5433/1679-0359.2016v37n1p17

PAPPAS, M. L.; BROUFAS, G. D.; KOVEOS, D. S. Chrysopid predators and their role in biological control. Journal of Entomology, London, v. 8, p. 301-326, 2011. https://doi.org/10.3923/je.2011.301.326

PAPPAS, M. L.; BROUFAS, G. D.; KOVEOS, D. S. Effect of temperature on survival, development and reproduction of the predatory lacewing Dichochrysa prasina (Neuroptera: Chrysopidae) reared on Ephestia kuehniella eggs (Lepidoptera: Pyralidae). Biological Control, Orlando, v. 45, p. 396-403, 2008. https://doi.org/10.1016/j.biocontrol.2008.02.005

PARRA, J. R. P.; BOTELHO, P. S. M.; CORRÊA-FERREIRA, B. S.; BENTO, J. M. S. Controle biológico: terminologia. In PARRA, J. R. P. (ed): Controle biológico no Brasil: parasitóides e predadores. São Paulo: Manole. 609 pp. 2002

PESSOA, L. G. A.; FREITAS, S.; LOUREIRO, E. S. Effect of temperature variation on Chrysoperla raimundoi Freitas \& Penny (Neuroptera: Chrysopidae) embryonic and post-embryonic development. Arquivos do Instituto Biológico, São Paulo, v. 76, p. 239-244, 2009.

RESENDE, A. L. S.; SOUZA, B.; AGUIAR-MENEZES, E. L.; OLIVEIRA, R. J.; CAMPOS, M. E. S. Influência de diferentes cultivos e fatores climáticos na ocorrência de crisopídeos em sistema agroecológico. Arquivos do Instituto Biológico, São Paulo, v. 81, p. 257-263, 2014. https://doi.org/10.1590/18081657001082012

SILVA, G. A.; CARVALHO, C. F.; SOUZA, B. Biological aspects of Chrysoperla externa (Hagen, 1861) (Neuroptera: Chrysopidae) fed on Alabama argillacea (Hübner, 1818) (Lepidoptera: Noctuidae). Ciência e Agrotecnologia, Lavras, v. 26, p. 682-698, 2002.

TAVARES, W. S.; CRUZ, I.; SILVA, R. B.; SERRÃO, J. E.; ZANUNCIO, J. C. Prey consumption and development of Chrysoperla externa (Neuroptera: Chrysopidae) on Spodoptera frugiperda (Lepidoptera: Noctuidae) eggs and larvae and Anagasta kuehniella (Lepidoptera: Pyralidae) eggs. Maydica, Bergamo, v. 56, p. 283-291, 2011.

VAN LENTEREN, J. C. The state of commercial augmentative biological control: plenty of natural enemies, but a frustrating lack of uptake. BioControl, Dordrecht, v. 57, p. 1-20, 2012. https://doi.org/10.1007/s10526011-9395-1 
Thermal requirements...

NUNES, G. S. et al.

VENZON, M.; ROSADO, M. C.; EUZÉBIO, D. E.; SOUZA, B.; SCHOEREDER, J. H. Suitability of leguminous cover crop pollens as food source for the green lacewing Chrysoperla externa (Hagen) (Neuroptera: Chrysopidae). Neotropical Entomology, Londrina, v. 35, p. 371-376, 2006.

https://doi.org/10.1590/S1519-566X2006000300012 